\title{
Sistem Informasi Pariwisata Daerah Kabupaten Nabire Berbasis Web
}

\author{
Filemon Duwitau $^{1^{*}}$, Rony Wijanarko ${ }^{2}$ \\ ${ }^{1,2}$ Jurusan Teknik Informatika,Fakultas Teknik Universitas Wahid Hasyim Semarang \\ Jl.Menoreh Tengah X/22,Sampangan,Semarang 50236. \\ "Email: mepasondegau@gmail.com
}

\begin{abstract}
Abstrak
Berkembangnya dunia media sosial seperti saat ini mengakibatkan tingkat keminatan masyarakat terhadap lokasi kunjungan pariwisata menjadi bertambah. Karena Pariwisata di Kabupaten Nabire memilik beraneka ragam wisata seperti Wisata pantai, Wisata alam, Wisata Buatan, Wisata Budaya. Potensi wisata yang dimiliki Kabupaten Nabire belum begitu terkenal sampai di masyarakat luas untuk dapat mengetahui destinasi wisata yang ada di Nabire. Penelitian ini mempunyai manfaat untuk pengembangan pariwisata dalam pembangunan dengan mengandalkan potensi wisata yang dimiliki oleh Kabupaten Nabire. Adapun metode pengumpulan data yang digunakan dalam penelitian ini yaitu wawancara, pengamatan dan dokumentasi. Dalam penelitian ini menunjukkan bahwa masih kurangnya pengelolaan dalam pengembangan pariwisata disebabkan masih kurangnya sumber daya manusia berbasis kepariwisataan. Fasilitas penunjang di setiap kawasan wisata juga masih sangat kurang. Pada penelitian ini dirancang sebuah sistem informasi pariwisata kabupaten Nabire berbasis web untuk mempermudah wisatawan yang ingin berkunjung ke wisata nabire dengan sistem online. Dengan adanya sisem informasi wisata ini mudah mencari lokasi, dan nama wisata yang ada di kabupaten Nabire. Sistem informasi pariwisata ini dapat menampilkan alamat wisata dan rute dari lokasi pengguna menuju lokasi wisata dengan Google MapAPI. Sistem infomasi wisata ini dirancang menggunakan bahasa pemograman PHP dan Mysql sebagai databasenya. Sistem informasi wisata ini dapat menampilkan nama wisata yang dipilih, selain itu Sistem informasi wisata ini juga dapat menunjukan rute dari lokasi pengguna menuju lokasi Wisata.
\end{abstract}

Kata Kunci : Google Map API, Sistem Informasi Objek Wisata.

\section{PENDAHULUAN}

\subsection{Latar Belakang}

Berkembangnya dunia media sosial seperti saat ini mengakibatkan tingkat keminatan masyarakat terhadap lokasi kunjungan menjadi bertambah. Pemilihan lokasi kunjungan pariwisata secara tidak langsung berpengaruh pada eksistensi masyarakat terutama didunia maya secara serentak masyarakat berlomba-lomba berfoto ditempat wisata yang sesuai dengan keinginannya.Industri pariwisata adalah kumpulan usaha pariwisata yang saling terkait dalam rangka menghasilkan barang atau jasa bagi pemenuhan kebutuhan wisatawan dalam penyelenggaraan pariwisata. UndangUndang Pariwisata No 10 tahun 2009 industri pariwisata menjadi bagian penting dari sebuah wilayah karena hal ini merupakan salah satualat untuk mendongkrak dan menarik wisatawan untuk berkunjung di wilayah tersebut pariwisata merupakan sektor unggulan yang diharapkan untuk menggerakan roda perekonomian indonesia dijadikan pariwisata sebagai sektor unggulan, tidak lain karena dampak yang mampu ditimbulkan dari aktivitas pariwisata yang begitu besar terhadap Ekonomi,Sosial, maupun lingkungan.

Daerah tujuan wisata merupakan salah satu komponen penting sumber daya pariwisata faktor geografi merupakan faktor penting untuk pertimbangan pengembangan kepariwisataan, pendekatan geografi yang mendasarkan pada aspek keruangan mempunyai kaitan yang erat dengan persebaran dari suatu obyek pembahasan.Pengembangan pariwisata yang menggunakan pendekatan keruangan dapat dilihat dari kedudukan obyek wisata terhadap obyek wisata yang lain, hal ini dimaksudkan untuk melihat potensi yang di miliki obyek wisata dan adanya kemungkinan untuk dikembangkan atau berkembang

Kabupaten Nabire adalah salah satu kabupaten di provinsi Papua,Indonesia Ibu Kota kabupaten ini terletak di punggung Pulau Irian dengan Ibu Kota Nabire memiliki luas wilayah $15.357,55 \mathrm{~km}^{2}$, dan terletak diantara 134,35 BT - 136,37 dan 2,25 LS - 4,15 LS,Saat ini 
memang kabupaten nabire belum resmi ditetapkan sebagai daerah wisata karena potensi wisatanya yang masih belum menonjol. Hal ini salah satunya disebabkan oleh pengelolaan yang belum maksimal,sumber daya manusia yang belum mumpunyai sarana dan prasarana yang masih belum memadai. Namun sebenarnya nabire miliki potensi wisata alam yang sangat indah dan menawan untuk dijadikan tempat wisata unggulan papua pada khususnya Nabire.

\subsection{Tinjauan Studi}

Kota Nabire adalah salah satu kota kabupaten di provinsi Papua Indonesia yang terletak dipunggung burung pulau papua. pulau papua yang terbuka ke arah perairan teluk cendrawasih sangat pas dengan predikat yang disandangnya yaitu sebagai' Gerbang Nun Biru'.Disebut "Gerbang" karena kota ini menjadi akses utama menuju beberapa kabupaten di wilayah pegunungan Papua,seperti Paniai, Dogiyai, Deiyai, Jayawijaya, Puncak Jaya dan Intan Jaya.

Sektor Pariwisata di Kabupaten Nabire memiliki banyak potensi yang cukup baik untuk di kembangkan dalam hal ini konsep pengembangan di lihat dari dua aspek yaitu sumber daya alam dan sumber daya manusia,sumber daya alam cukup baik,namun sumber daya manusia dalam bidang kepariwisataan masih sangat kurang.Untuk itu harus adanya pelatihan khusus untuk peranan Sumber daya manusia yang berbasis kepawisataan agar dapat menunjang pariwisata di Kabupaten Nabire strategi konsep pengembangan sektor pariwisata di Kabupaten Nabire dalam meningkatkan pariwisata di Kabupaten Nabire.

Penelitian yang dilakukan oleh Melinda Ester Imbir dkk, (2015). Menjelaskan tentang studi pengembangan sektor pariwisata dikabupaten Nabire. Tujuannya untuk pengembangan pariwisata pantai Gedo kabupaten Nabire.

Hasil penelitian tersebut merupakan acuan yang relevan dengan penelitian ini,karena memiliki kesamaan terutama dalam hal mengembangkan suatu daerah tujuan wisata dengan tetap fokus pada prinsip pengembangan pariwisata,karena setiap kawasan ataupun destinasi pariwisata memerlukan pemasaran yang baik tanpa terkeculi. Salah satu upaya untuk mewujudkan kota Nabire sebagai destinsi pariwisata maka perlu adanya sinergi pemasaran dan pencitraan pariwisata daerah kabupaten Nabire itu sendiri agar dapat menjadi destinasi pariwisata yang terbaik khususnya di Nabire.

Perbedaannya sistem informasi wisata nabire mampu menampilkan artikel objek wisata juga mampu menampilkan peta lokasi wisata,dan rute dari pengguna menuju lokasi wisata tersebut karena website lain pada umumnya hanya berisi artikel, berita tentang wisata di kabupaten Nabire tetapi tidak memberikan peta lokasi.

\section{TINJAUAN PUSTAKA}

\subsection{Definisi Sistem}

Menurut fitGerald (1999) sebuah sistem terdiri dari beberapa bagian atau elemen yang saling berhubungan yang beroperasi secara bersama-sama untuk mencapai tujuan-tujuan dan sasaran tertentu.Sistem adalah suatu jaringan kerja dari prosedur-prosedur yang saling berhubungan, berkumpul bersama-sama untuk melakukan suatu kegiatan atau menyelesaikan suatu sasaran pada permasalahan tertentu.

Menurut Kadir (2001) sistem adalah sekumpulan elemen yang saling terkait atau terpadu yang dimaksudkan untuk mencapai suatu tujuan".dari kedua pengertian diatas dapat disimpulkan bahwa sistem adalah sekumpulan komponen-komponen atau bagian-bagian yang salingberkaitan antara yang satu dengan yang lainnya untuk mencapai tujuan yang sama.

Menurut Jogiyanto (2008) Sistem informasi marupakan suatusistem yang tujuannya menghasilkan informasi tugas dari sistem informasi adalah untuk melakukan siklus pengolahan data.Siklus pengolahan data (data processing life cylce) atau disebut juga dengan nama siklus informasi (information life cycle) .Sistem Informasi terdiri dari beberapa komponen yaitu komponen input, komponen model,komponen teknologi, komponen basis data dan komponen kontrol.

\subsection{Destinasi Wisata}

Destinasi adalah tempat yang dikunjungi dengan waktu yang signifikan selama perjalanan seseorang dibandingkan dengan tempat lain yang dilalui selama perjalanan (misalnya daerah transit). Penggolongan destinasi yaitu seperti berikut: 
1. Destinasi sumber daya alam seperti iklim, pantai, hutan;

2. Destinasi sumber daya budaya seperti tempat bersejarah, museum, teater, danmasyarakat lokal;

3. Fasilitas rekreasi seperti taman hiburan.

4. Event seperti Pesta Kesenian Bali, Pesta Danau Toba, pasar malam dan sebagainya.

Disebutkan dalam Undang-Undang Nomor 10 tentang Kepariwisataan bahwa unsur produk wisata atau destinasi setidaknya ada 3 yaitu: Attraksi atau daya tarik wisata, Ammenities (fasilitas) dan Aksesbilitas (pelayanan) disingkat 3A pariwisata. Pengembangan destinasi wisata pada tingkatan tampak lahan setidaknya memperhitungkan 3 poin kunci tersebut.

\subsection{Pariwisata Kabupaten Nabire}

Daya tarik objek wisata yang ada di Kabupaten Nabire utamanya adalah wisata alam, wisata bahari, wisata seni dan budaya, wisata sejarah dan wisata kuliner. Khusus wisata bahari sangat diminati oleh para touris manca negara (wisman) dalam bentuk kegiatan diving (menyelam) maupun memancing.

\section{METODOLOGI PENELITIAN}

\subsection{Waktu dan Tempat Penelitian}

Penelitian dilakukan tanggal 7 Juni 2018 sampai dengan 19 Juli 2018. Tempat penelitian dilakukan pada Dinas Kebudayaan Pariwisata Pemuda dan Olahraga Kabupaten Nabire yang beralamat Jalan Merdeka No 53, Kabupaten Nabire - Provinsi Papua, Telp. (0984) 23001.

\subsection{Prosedur Penelitian}

Prosedur penelitian adalah langkahlangkah atau cara-cara yang digunakan sebagai alat untuk mengumpulkan data dan menjawab pertanyaan-pertanyaan seputar penelitian. Bagian prosedur penelitian ini berisi penjelasan teknik pengumpulan data, jenis data, dan metode analisis data yang digunakan dalam penelitian.

\subsection{Teknik Mengumpulkan Data}

Teknik pengumpulan data yang di gunakan adalah:

1. Teknik observasi yaitu dengan melakukan pengamatan secara langsung di Dinas

Kebudayaan Pariwisata Pemuda dan Olahraga Kabupaten Nabire.
2. Teknik wawancara yaitu dengan cara melakukan tanya jawab secara langsung kepada pihak-pihak yang berada dalam lingkungan kedinasan.

3. Teknik kepustakaan yaitu dengan mengumpulkan data dari buku atau bahan tulisan yang ada relevansinya dengan penilitian ini.

\subsection{Jenis Data}

Data yang diperlukan untuk mengerjakan adalah sebagai berikut:

1. Data primer yakni data utama yang diperoleh secara langsung dari sumbernya.

Data diperoleh dengan melakukan wawancara,tanya jawab langsung oleh peneliti kepada pihak-pihak yang terkait dengan pokok permasalahan dalam pembuatan sistem informasi ini.

2. Data sekunder yakni data pelengkap, dikumpulkan dengan cara mempelajari dan menelaah dokumen yang berkaitan dengan pengembangan sistem informasi pariwisata. Dokumen yang dipelajari dapat bersumber dari buku-buku, referensi internet maupun dari dokumen langsung dari Dinas Pariwisata Kabupaten Nabire.

\subsection{Model Proses Pengembangan Perangkat Lunak}

Teori (Sommerville,2011). Diberikan pengembangan perangkat lunak mengikuti model proses waterfall

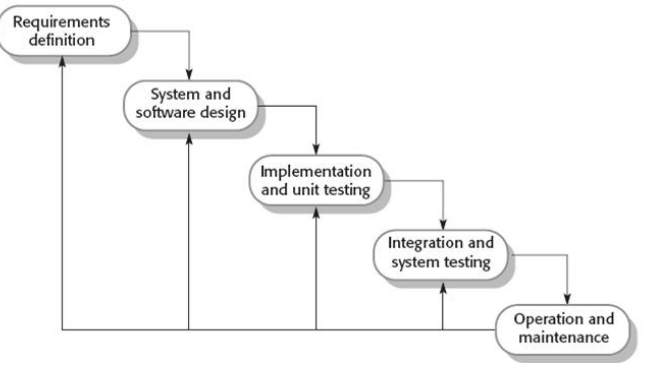

Gambar 1 Diagram proses waterfall (Sommerville, 2016).

Tahapan pengembangan perangkat lunak secara lebih detil dijelaskan sebagai berikut :

1. Mendefinisikan kebutuhan (requirement definition) Tahap mengenali kebutuhan dan menyatakan kebutuhan dalam narasi deskriptif atau dalam daftar spesifikasi kebutuhan software (software requirement specification). Selain kebutuhan fungsional dan kebutuhan 
non fungsional software, definisi kebutuhan akan dilengkapi dengan kebutuhan data dan informasi, kebutuhan perangkat keras, dan kebutuhan perangkat lunak pengembangan sistem.

2. Perancangan sistem dan perancangan perangkat lunak (system and software design)

Tahap perancangan yaitu tahap merencanakan cara memenuhi kebutuhan-kebutuhan spesifikasi perangkat lunak. Perancangan yang akan dilakukan meliputi perancangan proses, perancangan basisdata, dan perancangan tampilan.

Rancangan dikomunikasikan menggunakan bahasa pemodelan Unified Modeling Language (UML) dengan menggunakan usecase diagram, activity diagram, sequence diagram, dan class diagram.

3. Implementasi dan unit testing (impelentation and unit testing)

Tahap implementasi yaitu tahapan pembuatan kode program untuk mewujudkan rancangan. Perangkat lunak akan diimplementasikanmenggunakan bahasa perograman web atau bahasa script web PHP dengan didukung penggunaan script HTML, CSS, dan javascript.Unit testing adalah pengujian bagian program skala kecil yang di lakukan segera setelah suatu kode atau bagian program selesai dibuat.

4. Pengujian integrasi dan pengujian sistem (integration and system testing)

Pengujian integrasi dan pengujian sistem adalah pengujian perangkat lunak secara keseluruhan setelah semua spesifikasi sistem selesai di buat Selanjutnya pengujian sistem dan pengujian penerimaan dilaksanakan Pengujian dilakukan dengan menggunakan pengujian blackbox,yaitu menguji apakah dengan memberikan input tertentu sistem dapat memberikan output sesuai yang diharapkan.Pengujian hanya berfokus pada input output tanpa melihat proses didalamnya.

5. Penerapan dan perawatan (operation and maintenance)

Tahap penerapan adalah tahap menempatkan perangkat lunak disebuah server diinternet agar perangkat lunak dapat digunakan atau operasional.Selanjutnya perangkat lunak akan membutuhkan perawatan yaitu pengawasan, perbaikan bug, dan penambahan atau melengkapi fitur apabila dibutuhkan.

\subsection{Desain atau Perancangan Sistem}

Hasil tahap analisa menjadi bahan yang digunakan dalam tahap desain atau perancangan sistem sebagai cara untuk mendapatkan pemecahan masalah alternatif yang dapat diusulkan dalam penerapan sistem. Pada tahap ini dilakukan pemodelan untuk modul-modul, proses, database dan alur sistem yang akan dibuat.

Kebutuhan fitur sistem sebagai hasil analisis dapat dimodelkan dengan usecase diagram seperti yang ditunjukkan pada Gambar 2 usecase diagram website sistem informasi pariwisata kabupaten nabire.

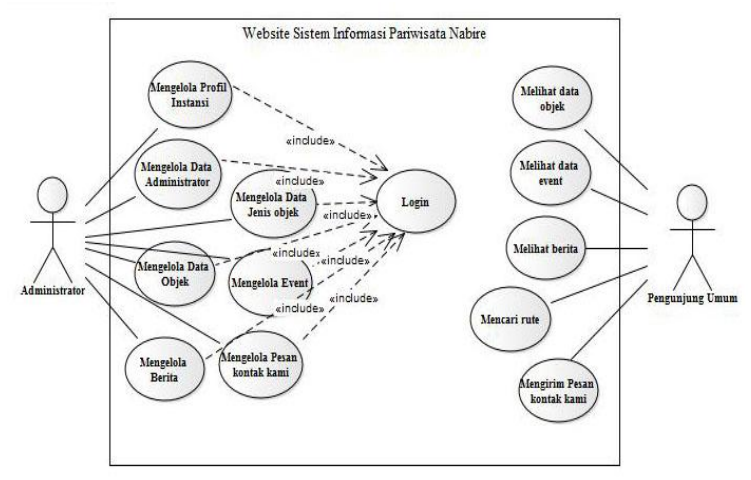

Gambar 2. Usecase diagram website Sistem Informasi Pariwisata Kabupaten Nabire

Penjelasan Usecase diagram website Sistem Informasi Pariwisata Kabupaten Nabire Pengguna sistem :

1. Administrator adalah pegawai/ petugas yang diberikan kewenangan untuk mengelola data sistem informasi pariwisata oleh dinas pariwisata kabupaten Nabire.

2. Pengunjung umum adalah masyarakat umum yang mengakses website sistem informasi pariwisata kabupaten Nabire.

\subsubsection{Perancangan proses}

1. Perancangan proses login

Proses login dibutuhkan untuk autentifikasi atau mengenali pengguna yang berhak masuk dan menggunakan menu sistem.

Rancangan proses login ditunjukkan dengan Gambar 3 activity diagram proses login, dan rancangan urutan perintah di dalam perangkat lunak ditunjukkan dengan gambar 4 sequence diagram proses login. 


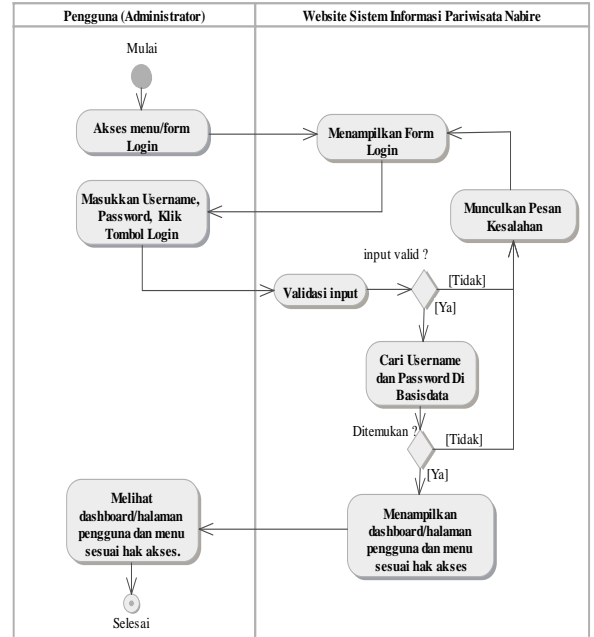

Gambar 3 activity diagram proses login

Gambar 3 activity diagram Proses login dibutuhkan untuk autentifikasi atau mengenali pengguna yang berhak masuk dan menggunakan menu sistem.

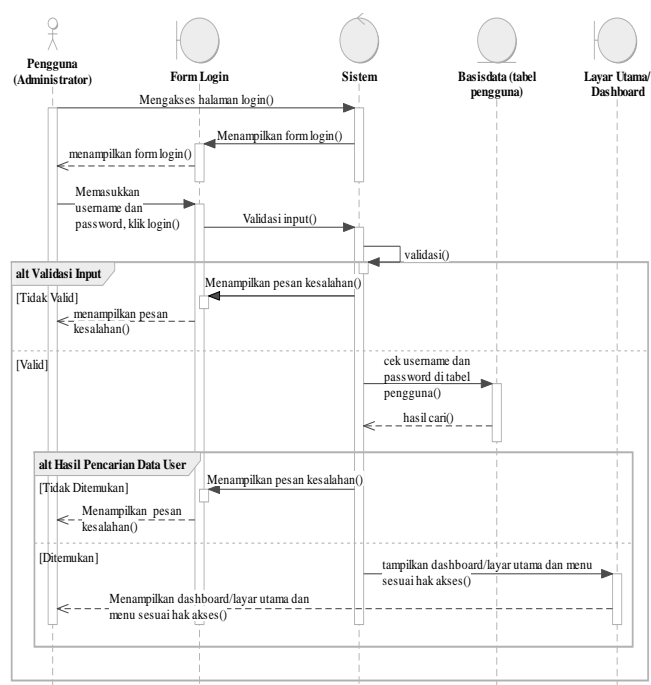

Gambar 4 sequence diagram proses login

Gambar 4 sequence diagram proses login Pengguna mengakses halaman atau form login, kemudian memasukkan username dan password, klik tombol login. Pada proses login terdapat dua kali validasi, yaitu validasi input dan validasi data didalam basisdata. Validasi input untuk memeriksa kelengkapan inputan pengguna.Jika input username atau password kosong, sistem akan menampilkanpesan kesalahan. Jika input lengkap, sistem akan menjalankan validasi kedua yaitu mencari keberadaan akun login dibasisdata. Jika akun yang dimasukkan tidak ditemukan, sistem akan membuka halaman login kembali dengan memberikan pesan kesalahan. Jika akun yang dimasukkan benar atau ditemukan di basisdata, sistem akan memberikan halaman dashboard pengguna dan menu sesuai hak aksesnya.

2. Perancangan proses mengelola profil instansi

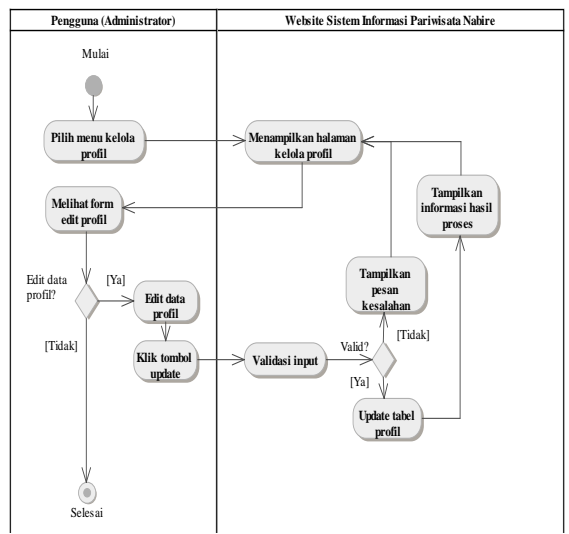

Gambar 5 Activity diagram mengelola profil instansi

Gambar 5 Activity diagram mengelola profil instansi Setelah login, administrator dapat mengelola atau mengubah data profil instansi. Rancangan urutan proses mengelola profil instansi ditunjukkan dengan gambar 5 activity diagram mengelola profil instansi, dan rancangan urutan perintah di dalam program ditunjukkan dengan gambar 6 sequence diagram mengelola profil instansi.

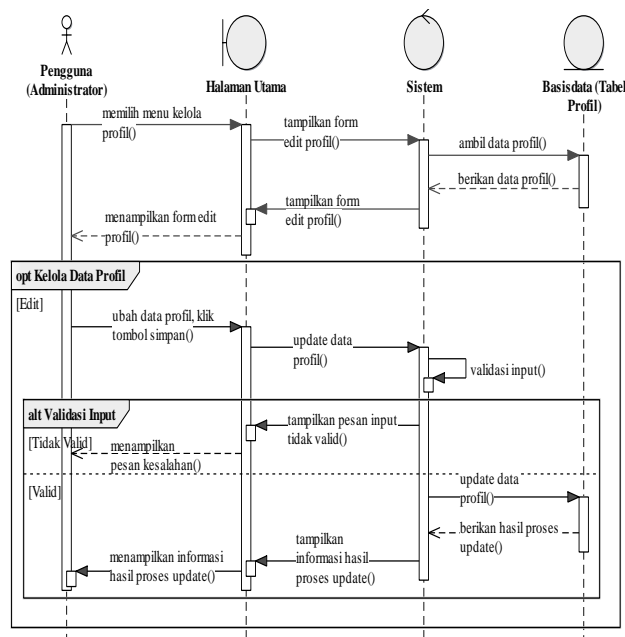


Gambar 6 Sequence diagram mengelola profil instansi

Gambar 6 Sequence diagram mengelola profil instansi Urutan langkah mengelola data profil yaitu: Pengguna memilih menu profil, Sistem akan menampilkan form edit profil,Pengguna mengubah data profil, klik tombol simpan,Sistem akan melakukan validasi input,Jika input tidak valid, sistem akan menampilkan pesan kesalahan atau pesan input tidak valid. Jika input valid, sistem akan menyimpan data ke tabel profil, Sistem menampilkan informasi hasil proses update.

3. Perancangan proses kelola data administrator

Super admindapat mengelola data administrator yaitu menambah, mengubah, dan menghapus data administrator.

Rancangan urutan proses mengelola data administrator ditunjukkan dengan gambar 7 activity diagrammengelola data administrator, dan rancangan urutan perintah di dalam program ditunjukkan dengan gambar 8 sequence diagram mengelola data administrator.

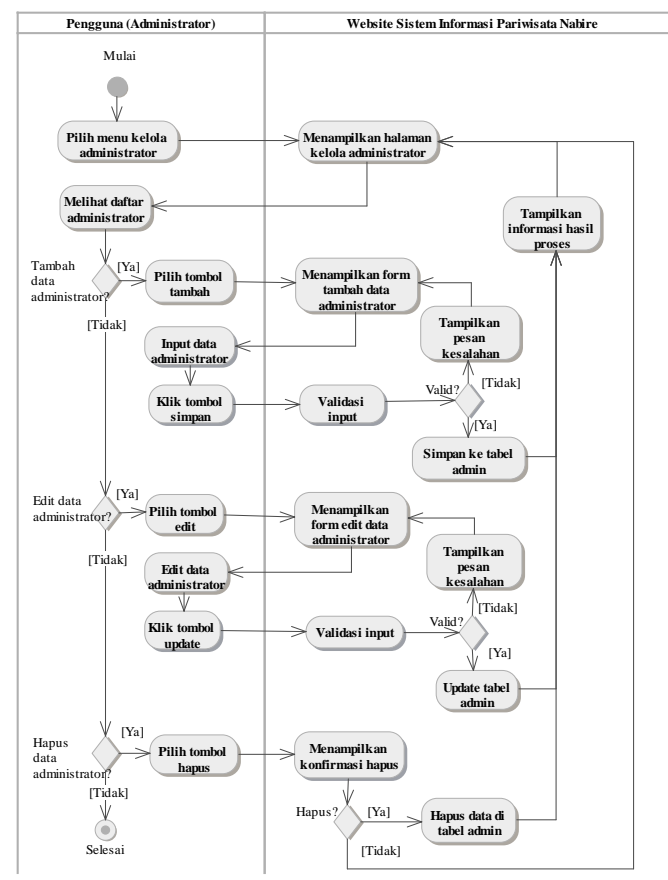

Gambar 7 Activity diagram mengelola data administrator
Gambar 7 Activity diagram Super admin dapat mengelola data administrator yaitu menambah, mengubah, dan menghapus data administrator.

\subsubsection{Perancangan basisdata}

Basisdata dirancang menggunakan class diagram. Class mewakili objek sistem yang datanya disimpan permanen dalam basisdata, atau mewakili tabel di basisdata.

Class diagram untuk merancang basisdata ditunjukkan dengan Gambar 8 class diagram perancangan basisdata.
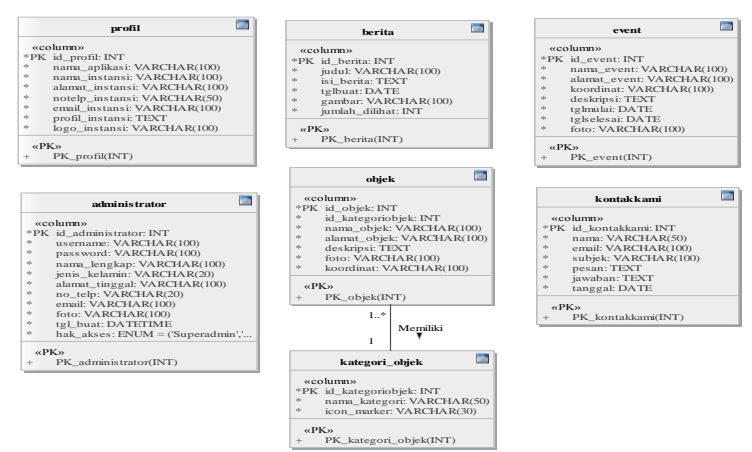

Gambar 8 Class diagram perancangan basisdata

Gambar 8 Class diagram perancangan basisdata,Berdasarkan class diagram Gambar 8, tabel yang akan dibuat untuk memenuhi kebutuhan website sistem informasi pariwisata kabupaten nabire yaitu tabel administrator, profil, berita, event, kategori_objek, objek, dan kontakkami.

Lambang Class melambangkan tabel, oleh sebab itu diberikan stereotype icon tabel dikanan atas yang menjelaskan bahwa class tersebut mewakili sebuah tabel.

\subsubsection{Perancangan User Interface}

Rancangan untuk tampilan yang sering dilakukan adalah merancang struktur menu dan merancang tata letak dari halaman atau formulir dalam program. Rancangan struktur menu dilakukan dengan membuat sitemap atau ada yang menyebut HIPO (Hierarchy Input Process Output), dan rancangan tata letak dilakukan dengan membuat wireframe diagram. 


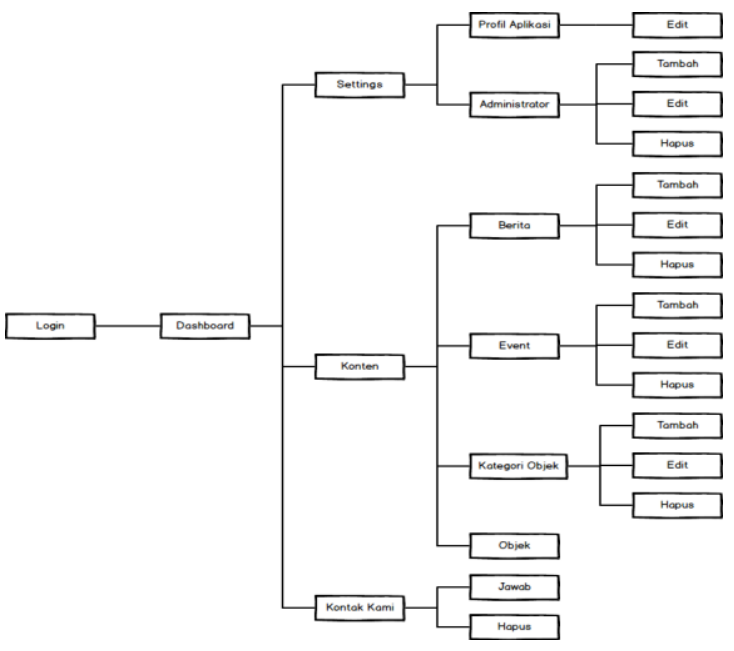

Gambar 9 Struktur menu administrator

Gambar 9 Struktur menu administrator Rancangan untuk tampilan yang sering dilakukan adalah merancang struktur menu dan merancang tata letak dari halaman atau formulir dalam program.

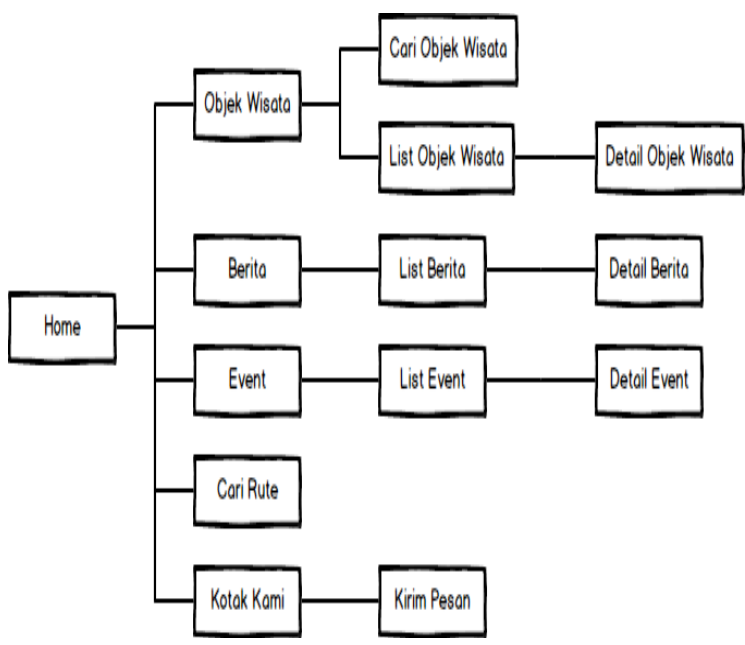

Gambar 10 Struktur menu pengunjung umum

Gambar 10 Struktur menu pengunjung umum Rancangan tata letak halaman ditunjukkan sebagai berikut :

1. Rancangan halaman home website

Halaman home adalah halaman yang diberikan kepada pengunjung umum pada saat pertama kali mengakses website pariwisata kabupaten nabire.

Rancangan halaman home ditunjukkan dengan gambar 10 rancangan tampilan halaman home.

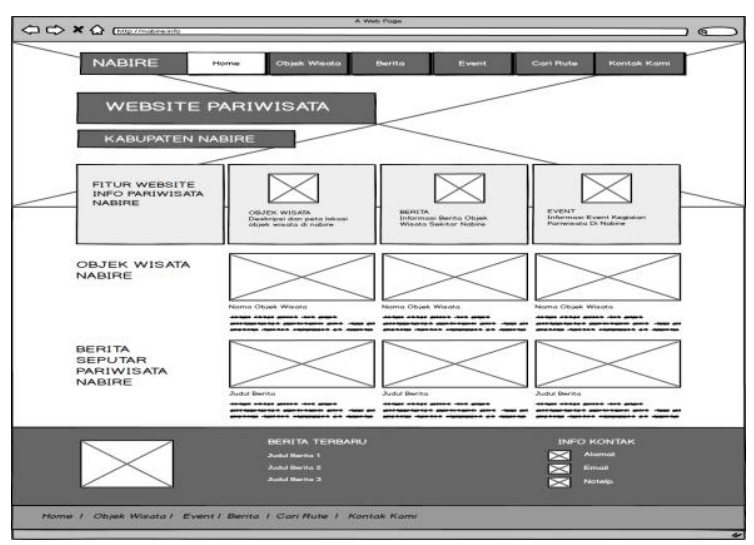

Gambar 11 Rancangan tampilan halaman home

Gambar 11 Rancangan tampilan halaman home bertujuan untuk memberikan kesan pertama yang terbaik kepada pengunjung. Informasi pemilik aplikasi dan konten atau isi website harus segera tergambarkan di halaman home.

Di halaman home, di bagian atas diletakkan menu utama yang terdiri atas menu home, objek wisata, berita, event, cari rute, dan kontak kami. Di bagian atas juga diletakkan gambar slider yang menunjukkan gambargambar objek wisata di kabupaten Nabire. Dibagian bawahnya diletakkan teaser yang objek wisata dan berita. Bagian paling bawah diletakkan logo instansi, info kontak, dan menu sekunder yang sama dengan menu utama.

\section{HASIL DAN PEMBAHASAN}

Hasil website sistem informasi pariwisata kabupaten Nabire.Hasil ini akan ditunjukkan melalui screenshoottampilan jalannya website sistem informasi sebagai berikut :

1. Hasil halaman home website

Halaman home dibuat mengikuti rancangan proses dan rancangan tampilan yang diberikan. Hasil halaman home ditunjukkan dengan gambar 12. 


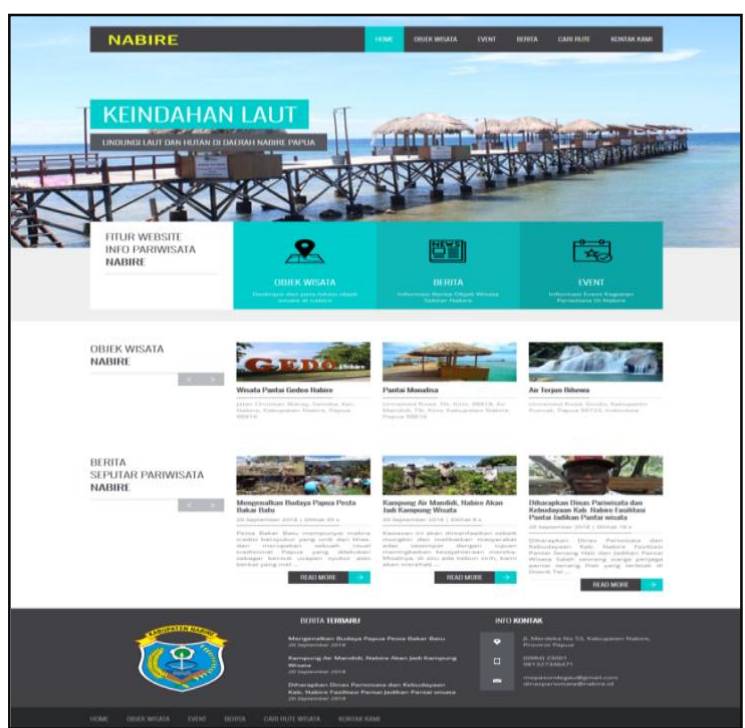

Gambar 12 Hasil halaman home

Gambar 12 Hasil halaman home Pengunjung umum harus mengetahui alamat website dan mengetikkan alamat website diweb browser, kemudian klik enter.Web browser akan menampilkan halaman home.

2. Hasil halaman objek wisata dan detil objek wisata

Halaman objek wisata dan halaman detil objek wisata dibuat mengikuti rancangan proses dan rancangan tampilan untuk memenuhi usecase melihat data objek wisata bagi pengunjung umum.

Hasil halaman objek wisata dan halaman detil objek wisata ditunjukkan dengan gambar 13 hasil halaman objek wisata

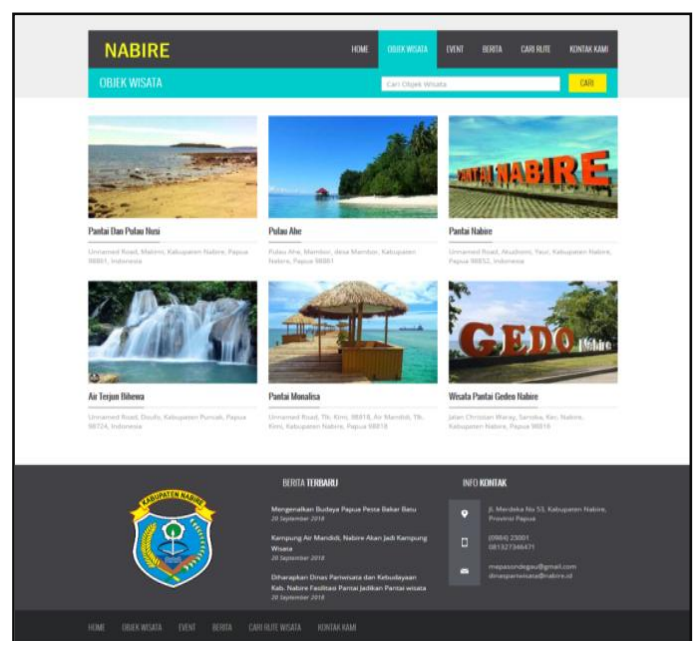

Gambar 13 Hasil halaman objek wisata
Gambar 13 Hasil halaman objek wisata Pengunjung umum dapat menampilkan halaman objek wisata dengan memilih menu objek wisata. Pengunjung umum dapat mencari data objek wisata melalui form pencarian objek wisata dibagian kanan atas.

\section{KESIMPULAN}

Penelitian telah berhasil menghasilkan website sistem informasi pariwisata kabupaten Nabire yang dapat digunakan oleh pengunjung umum atau masyarakat umum dan oleh administrator sistem atau pegawai dinas pariwisata kabupaten Nabire. Masyarakat umum dapat menggunakan website untuk menampilkan data objek wisata, data event, data berita, mencari objek wisata, mencari rute, dan mengirimkan pesan kontak kami. Administrator menggunakan sistem informasi untuk mengelola data profil instansi, mengelola data administrator, mengelola data berita, mengelola data event mengelola data kategori objek, mengelola data objek, dan mengelola pesan kontak kami.

Beberapa objek wisata di kabupaten Nabire yang berhasil diidentifikasi dan telah dimasukkan dalam basisdata sistem yaitu objek wisata wisata pantai gedeo, pantai monalisa, air terjun bihewa, pantai nabire, pulau ahe, dan pantai dan pulau nusi.Sistem informasi juga telah menyimpan beberapa objek lainnya seperti pelabuhan, bandara, penginapan, tempat makan, dan tempat ibadah.Website sistem informasi pariwisata yang telah dibuat diharapkan akan menjadi media informasi atau media promosi objek-objek pariwisata di kabupaten Nabire yang dapat diakses oleh masyarakat luas secara mudah, murah, dimana saja, dan kapan saja.

\section{SARAN}

Adapun saran yang dapat penulis berikan adalah sebagai berikut :

a. Dalam pembangunan pariwisata kabupaten Nabire, Pemerintah daerah khsusnya Dinas Pariwisata perlu mempromosikan pariwisata dengan membuat event-event festival budaya nabire sebagai cara untuk menarik simpati wisatawan terhadap Nabire. Selain itu Dinas Pariwisata harus melakukan promosi melalui website agar wisatawan luar dapat mengetahui keindahan pariwisata yang terdapat di kabupaten nabire. 
b. Sistem Informasi pariwisata kabupaten nabire dapat menjadi destinasi wisata favorit bagi wisatawan baik lokal bahkan mancanegara, maka pemerintah daerah melalui Dinas Pariwisata harus membangun tempat tempat wisata yang jau lebih baik.

c. Sistem informasi ini masih sederhana perlu fitur-fitur baru dan menarik sebagai penyempurnaan.

d. Sistem informasi pariwisata ini dikembangkan berbasis Adroid.

DAFTAR PUSTAKA

Kadir A, (2001). Pengenalan Sistem Informasi Edisi Revisi. Andi. Yogyakarta.

FitzGerald J., (1999). Analisis dan Perancangan Sistem Informasi. Jakarta Andi Publisher

Jogiyanto H.M, (2008). Analisis dan Desain Sistem Informasi. Jakarta : Andi Publisher

Imbir M. E, Makarau V. H, Jefferson L. (2015). Studi pengembangan sektor pariwisata di kabupaten Nabire. Jurnal Spasial : Perencanaan Wilayah dan Kota. Vol. 2 No. 3.

Sommerville, Ian. (2011). Software Engineering (Rekayasa Perangkat Lunak). Jakarta: Erlangga 